\title{
Lord Kerr of Tonaghmore
}

Tam grateful to the Northern Ireland Legal Quarterly for the opportunity to pay tribute to my former colleague and predecessor, Lord Kerr of Tonaghmore. I would like to associate myself, on behalf of Northern Ireland's judiciary, with Professor Dickson's tribute in the journal.

Lord Kerr's distinguished career has been summarily captured often in recent months for it is only in late September this year that he retired from the Supreme Court as its longest serving Justice, holding office since the Court's inception in 2009. It was the intention of Northern Ireland's Court of Judicature to welcome home one of our finest to mark his service and celebrate his renowned contribution to the administration of justice. Sadly, Brian's sudden passing leaves me to pay tribute to him in a different way.

I served under Brian Kerr as a High Court judge during his tenure as Lord Chief Justice of Northern Ireland. I had the benefit of working with not only a fine lawyer but a considerate, good humoured and compassionate colleague. Brian's contribution to the law is enshrined in his important and often fearless judgments but was also captured by his relentless challenge to all who served alongside him and to those who appeared in front of him, to think - always intensely. Brian reflected deeply on the cases he heard. He was thorough, thoughtful and adept at tempering legal reasoning with common sense.

Brian Kerr held judicial office for 27 years, moving from the High Court bench, to the Court of Appeal as Lord Chief Justice; from there to being the last Lord of Appeal in Ordinary in the House of Lords to becoming the youngest of the justices in the newly formed Supreme Court. Judicial office is an independent one, where decisions must be made individually and frequent periods of working alone are demanded. This was true for Brian too, but his ability to support, inspire and assist colleagues and support staff alike was immeasurable.

Brian was a pioneer in the courts of Northern Ireland and London. He recognised at an early juncture the importance of the use of IT in courts and the assistance judges needed to perform their roles as efficiently as possible. He established a legal team in the Office of the Lord Chief Justice to support judges in their administration of justice. When he moved to the Supreme Court, he was responsible for the judicial assistants' programme, based on the model he had established in Belfast. Likewise, he used his experience to advance the use of IT in the Supreme Court; as Lord Reed has recently noted, allowing that Court to operate effectively during the current pandemic. 
Brian Kerr was the epitome of an independent judge. He was never afraid to challenge and provide counterbalance to different legalistic approaches. He never lost sight of the society he served or the interests of the vulnerable. He sought to hold the executive to account; to balance the intervention of the State with the individual rights of citizens. He was one of the justices who heard both the 2016 Article 50 Brexit case and the 2019 prorogation of Parliament case, in which he was described as 'an active and close questioner of the government's submissions'. The government lost both cases when the justices upheld Parliament's sovereignty and its powers to scrutinise legislation.

Shortly after his retirement, Brian noted that:

The government's position ought to be strongly tested ... It was an intensely interesting case. I failed to resist the temptation to ask questions.

Brian Kerr stood out for his willingness to ask questions in order that justice was served. His service to society was outstanding and the body of jurisprudence he leaves will continue to inform and benefit us for many years. A significant proportion of his judgments were dissenting - always questioning and thoroughly independently minded. It was my honour to have been his colleague and friend.

Sir Declan Morgan, Lord Chief Justice of Northern Ireland 